\title{
SUSTAINABLE CORPORATE GROWTH: RELATIONSHIP BETWEEN LIFE CYCLE CONCEPTS AND FINANCIAL AND ECONOMIC FACTORS, PROBABILISTIC MODELING
}

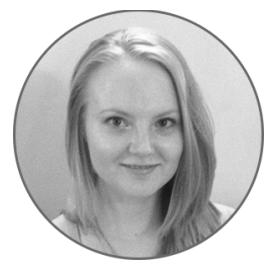

Article history:

Received 7 July 2017

Received in revised form

17 July 2017

Accepted 27 July 2017

Translated 9 October 2017

Available online 14 December 2017

JEL classification: $\mathrm{C}, \mathrm{G} 32,012$

Keywords: life cycle, development, sustainable growth, probability

\begin{abstract}
Importance The article considers the issue of the company's transition to sustainable growth and investigates the trade-off of its performance and life cycle phases.

Objectives The research aims to substantiate the hypothesis stating that a system integration concept of sustainable growth should be developed in line with changes in financial and economic characteristics at different phases of life cycle. I also identify an impact on the probability of transition to a new phase and determine significant drivers of instability.

Methods I construct logistic regression models based on panel data of public companies to assess the impact of financial and economic factors on corporate growth and model the probability of unsustainable growth. I apply graphical analysis methods. The probability is assessed by calculating partial derivatives of a composite function. Results The research states the need to take into consideration the organization's life cycle concept while examining its condition, underpins the expediency of developing a system integration concept to study company's growth. Using the economic and mathematical methods of analysis, I evaluate and quantify an impact on life cycle phases, calculate the probability of unsustainable growth depending on financial leverage and slow growth phase. Conclusions and Relevance It is important to consider life cycle phases when studying the company's operations. Management should adhere to probabilistic modeling results in order to create forecasts and scenarios of development, potential threats, and motivating factors.
\end{abstract}

\section{Introduction}

Contemporary models subject to testing often imply such concepts as corporate sustainability and unsustainability. It directly alludes to financial and business results of corporate operations. Revenue, profitability, indirect indicator of corporate value measured through the ratio of the company

${ }^{\dagger}$ For the source article, please refer to: Красильникова Е.В.

Устойчивый рост компании: связь концепций жизненного цикла и финансово-экономических факторов, моделирование вероятности. Экономический анализ: теория и практика, 2017. Т. 16. Вып. 8. C. 1400-1419. URL: https://doi.org/10.24891/ea.16.8.1400 capitalization to its carrying amount usually become those factors that attract researchers.

Findings, more often than not, hinder conclusions to be made on the way corporate performance correlates with endogenous and exogenous factors by including independent variables.

Researchers generally choose large and mature companies to study the way the factors influence corporate sustainability.

Entities are not static. Characteristics of mature entities differ from the specifics and factors of growing entities. 
If analyzable entities are divided by phase of their life cycle, it will streamline the modification of models, specify empirical results of researches.

Identifying the entity's life cycle phase helps analyze its growth pace, determine its trends at different development stages and factors which influence the corporate sustainability at certain phases of the life cycle.

\section{Research Methods}

Controversial results of researches into financial and economic indicators often stem from different samples of companies operating in advanced or emerging markets, and different ownership structure.

If certain groups of owners prevail, it has a distinct impact of the decision making process, strategy and performance.

The specifics of the ownership structure and corporate relationship are one of the key metrics reflecting a qualitative growth of any company.

The high ownership concentration is conventionally regarded as a negative factor that influences the corporate performance, since the high concentration of ownership presumably affects minority shareholders.

As for the Russian companies, this corporate culture quality has been as a shield protecting them from hostile takeovers.

Corporate relationship becomes more harmonized and stable if there is a large shareholder interested in the long-term operations of the company.

Hence, the ownership structure can be viewed as an advantage and a motivation for a corporate growth as well as its sustainability threat.

Methods for measuring the ownership structure relations and critical metrics of the company's financial and economic health are designated to scientifically assess an impact the factors have on performance results and development opportunities.

Generally, financial and economic efficiency indicators are independent variables in models, indicating the ratio of benefits, returns and costs.
Profitability is a crucial indicator that reflects the entity's efficiency in line with its financial and economic policies.

Trends in the market price, more or less, describe the way the corporate performance and potential change. However, the indicator is not always a good metric of the company's investing and innovative activities since it is significantly exposed to external factors and environment.

Individual indicators of efficiency are also applied, i.e. the return on certain types of resources, labor productivity, return on equity, etc.

Based on the empirical analysis, some hypotheses were outlined and approved. The hypotheses state that types of owners and their ownership size influence the business and financial performance [1-3]:

- entities have the best performance indicators if their share capital is held by a great deal of managers and, to a lesser extent, employees;

- the higher ownership concentration is, the higher the corporate performance is;

- the earlier the entity goes private, the more efficient it is;

- privatization processes turn even more efficient, if the percentage of outsiders increases in the share capital;

- if the percentage of foreign investors increases, such owners start to have a more positive impact on performance results.

High concentration of capital is proved to have a positive effect on efficiency indicators (performance rate measured as the ratio of sales volume and the number of employees). However, the difference is immaterial in case of medians.

Labor productivity increased in 61 percent of joint stock companies with the medium concentration of capital, 55 percent with high concentration and 44 percent with the low concentration [4].

The Russian and foreign authors mostly examine corporate performance factors using large companies' data, though neglecting the corporate development phase, which may have an absolutely different impact on sustainability. 
Risk premium associated with the life cycle phase can range from 0-10 percent ${ }^{1}$.

Studies into development phase issues, in fact, simply modify the corporate life cycle concept from descriptive organizational characteristics to a methodology.

The existing scientific proceedings on corporate development basically rely upon principles of L.E. Greiner and I. Adizes who paved the way for the life cycle theory [5-8].

Greiner's life cycle model [5] outlines several development phases that diverge by distinction in corporate relations. Corporate performance issues have been examined to a lesser extent.

The initial phase of the life cycle is called a growth through creativity. At this phase, initiating shareholders undertake business activities and implement their ideas. The phase reveals whether the activities are coordinated or not. Initiators may be trapped in leadership crises, thus posing a threat to the entity.

The following phase aims to formalize and centralize the decision-making process, being called a growth through direction. Corporate growth is driven through the corporate management enhancement.

As corporate relationships are built up, professional managers are involved and may fuel the leadership crisis among the owners. The company grows afterwards by making its activities more complicated and comprehensive, consolidating and merging with other businesses.

At the delegation phase, the governance system is decentralized, with the immediate responsibility and benefits of departments' leaders being raised. However, the decentralization induces the crisis of control.

The co-ordination phase multiplies the number of independent projects by setting up planning centers, thus igniting the crisis of boundaries.

At the cooperation phase, coordinated activities emerge. Team members are pondering the way they

\footnotetext{
${ }^{1}$ Goryunov E.V., Babicheva N.E., Kozlova L.V. [The influence of life cycle on business value evaluation]. Ekonomicheskii analiz: teoriya $i$ praktika = Economic Analysis: Theory and Practice, 2010, no. 30, pp. 35-42. (In Russ.)
}

should steer the development. Shall they orient at an inward or outward growth? Later on, the alliances phase comes as an additional stage of the outward growth.

The Adizes life cycle model $[7,8]$ points out a lot of phases. The courtship phase engenders a business idea, though the business is not yet set up. However, it is regarded as the initial phase of development.

This life cycle phase is accompanied with intrinsic issues of corporate relationships, such as uncertainty and doubts. At this phase unforeseen problems also arise, such as profit-making motivation, zero doubts. The corporate growth is driven by the entrepreneur's confidence in his/her idea.

The courtship phase may not come into being, if the founder's idea fades away. At the birth phase, the company is set up. This phase requires an active increment in current assets and persisting confidence in the business idea.

The company has an account of the difference among cash flows from operating, financing and investing activities, when the negative cash flow is a rule.

Deviations are supposed to include excessive control, zero feedback from the management, misuse of corporate funds for personal needs. At this life cycle phase, the crisis stems from insufficient investment and the founder's lost interest in the business idea.

The go-go phase sees a rapid growth in sales, cash flows and faces issues of frail corporate relationships and the founder's trap.

Hired leadership shall be involved. The adolescence implies the stewardship of hired managers. At this point, conflicts become possible at the corporate level, with prices for products still continuing to grow. The company grows and attains a new development phase by implementing the project mission and reinforcing confidence.

During the prime, possible risks and profit are balanced provided that the crisis does not invoke any changes and renovation investment. The stability rests on a reduction and zero increase in profit, short-term planning horizon. 
If the company makes investments for retrofitting its processes, it will prevent the continuous decline phase, i.e. aristocracy, meaning that the company mostly focuses on administrative expenses.

The early bureaucracy witnesses plunging sales and a revelation of causes. Restructuring becomes the sole option for growth. Otherwise the entity makes a step to the bureaucracy that is followed by the death.

Before the adolescence phase, the company is committed to sales, being constrained with profit and policies.

During the prime, the objective changes. Profit becomes important for the company, though its policies still remain a constraining objective.

After the aristocracy phase, the company abruptly shifts to constraining objectives of sales and profit, being guided by political aspects. The tendency gains momentum during the bureaucracy phase. Afterwards the business dies (Fig. 1).

Basic researches into corporate life cycles frame new concepts, which not only provide qualitative and descriptive characteristics of corporate challenges, but also assess key performance indicators. For example, the volatility of sales volume, retained earnings, return on assets [9-11].

Such researches usually deal with quantitative indicators and leave out the dynamics and variability of corporate relationships.

It is reasonable to mention a profound research by G.V. Shirokova concerning phase criteria and the specifics [12-14].

Development phases are marked with the company's age, corporate structure (evolving from simple one without functional subdivisions to functional, divisional and matrix-based structure) with numbers assigned. Passing through its development phases, the company formalizes its decision-making system, number of hierarchical levels (links in the longest chain of commands between the executive and working teams).

Descriptive variables include centralization, which is accounted as the extent to which the CEO is involved into decision-making processes, and the specialization level of the company.
I make a hypothesis assuming that agents' conflicts and ownership concentration have a non-linear impact on the way the company implements its strategy.

For purposes of the panel sample of the Russian companies, I determine the positive relation between the concentration and the occurrence of agents' controversies. The dependence is linear, since the sample includes large companies with the increased concentration of ownership.

I find the inverse dependence of the financial leverage level on the ownership concentration (Fig. 2, 3).

Based on data released by the largest public non-financial entities, I determine how the ownership concentration at various life cycles and performance indicators (the return on assets, in particular) correlate.

The U-shaped curve for age dependence and the inverse one are detected at the growth phase. During the decline, the concentration has a positive effect on indicators [15].

General principles for describing the life cycle of any system are promulgated in GOST $\mathrm{R}$ ISO/MEK 15288-2005 - Information Technology. System Engineering. Processes of Systems' Life Cycle.

Sales volume, resources, return on investment and relevant trends allow to assess the development type.

When the deviation (variance interval) exceeds 66.6 percent, it means the company is growing and using resources intensively. The interval of 33.3 through 66.6 percent signifies the maturity phase, when resources are used intensively and extensively. The interval of 14 percent through 33 percent is considered as the adolescence with the intensive and extensive use of resources. The interval under 14 percent is typical of the birth or death phases ${ }^{2}$.

Providing the more robust explanatory basis for conclusions, cognitive modeling is one of the methods for examining complex systems when the mathematical analysis is difficult to use.

\footnotetext{
${ }^{2}$ Lyubushin N.P., Babicheva N.E. [The life-cycle concept: From qualitative change description to quantitative assessment]. Ekonomicheskii analiz: teoriya i praktika = Economic Analysis: Theory and Practice, 2010, no. 23, pp. 2-9. (In Russ.)
} 
Cognitive mapping, or cognitive structuring, constitutes the methodology involving, analyzing and structuring the information.

Cognitive maps comprise base factors (the company's growth rate) and relationships. The weakness of the modeling method is that it fails to comprehensively evaluate the performance of projects $^{3}$.

\section{Problem Formulation}

Studying the relationship of financial and economic factors, corporate sustainability relies upon regression analysis models, which disregard the phase-related details and respective adjustments, thus having a dramatic impact on conclusions.

Life cycle concepts are examined with an emphasis on organizational changes, when corporate growth is driven by descriptive variables.

Models are modified in line with the phase of corporate development. Specifying the samples by including factors of the life cycle phases, I improve an empirical evaluation.

Efficiency, profitability and absolute values of income are explicit and conventional indicators of corporate performance.

The factors are static facts as of a certain date, rather than being cash flows.

Constructing a regression model that evaluates the effect of independent variables on corporate revenue or the return on assets by the method of least squares, it is possible to determine which factors make the indicators grow or stall.

However, prospects and opportunities of corporate growth are not easy to forecast. The conclusion stating that such relationships will remain permanent in the future is erroneous.

Therefore, the understanding of corporate development prospects requires a more ample evaluation of performance indicators based on the consistency principles, rather than as variables estimated in line with financial statements.

\footnotetext{
${ }^{3}$ Khrustalev E.Yu., Khrustalev O.E. [Cognitive modelling of knowledge-based industries development (on example of the militaryindustrial complex)]. Ekonomicheskii analiz: teoriya i praktika = Economic Analysis: Theory and Practice, 2013, no. 10, pp. 2-11. (In Russ.)
}

Future development and sustainability can be predicted with the integrative approach that aligns details of life cycle phases and model-based inference revealing how financial and economic indicators are influenced.

To modify the concept theoretically, corporate sustainable growth should be viewed as a system. Owners' preferences, specifics of corporate relationships constitute one of the crucial sub-systems of sustainable growth.

If economic processes are stable, internal driver of considerable development of a company are of crucial importance.

As one of its objectives, the research aims to trace the relationship among sub-systems and examine how the relationship variability change. Following the other objectives, I model key sustainability parameters and factors fueling the corporate unsustainability.

Hence, corporate sustainable growth is a complex, structural and protracted process that significantly differs at various phases of the life cycle.

\section{Growth Drivers and Corporate Sustainability in Scientific Concepts}

Financial sustainability shall mean the company is able to remain stable in a long run by analyzing its financial statements and financial ratios, in particular, such as liquidity, turnover of assets, debt management, profitability, market value ${ }^{4}$.

The company demonstrates financial and economic sustainability, if the allocation and use of its resources drive its development as profit and capital grow as well, while remaining solvent even under a tolerable risk. So, it requires a certain ratio of equity and borrowings, possibility to find additional resources through the issue of securities, development and market positioning capabilities [16].

Hence, it requires a flexible structure of financial resources, solvency and investment attractiveness.

Financial sustainability is a central component of the overall economic sustainability of the company,

\footnotetext{
${ }^{4}$ Brigham E.F., Ehrhardt M.C. Finansovyi menedzhment [Financial Management]. Saint Petersburg, Piter Publ., 2009, 960 p.
} 
i.e. the special state and trends in the structures of available resources and value, which relentlessly ensure high performance indicators and result from short-term productive and business processes and strategic managerial decisions.

The sustainability of economic systems depends on changes in results, consumable resources, while sustainability types correlate with the type of economic development ${ }^{5}$.

In the 1960s, management consulting studies focused on the issue and concept of corporate sustainable growth rates, with the main development pertaining to Boston Consulting Group.

Sustainable growth rate is considered as a possible and attainable pace of an increase in revenue from sales, while operating and financial policies remain unchanged. It is also defined as growth given net assets are profitable and borrowings can be used under the restricted debt-to-equity ratio and shareholders' policies for equity distribution.

As envisaged by corporate finance principles, the growth rate is a reinvested portion of earnings times the return on equity:

$$
g=r e i n v \cdot R O E=\left(1-\frac{\text { declare_div }}{N I}\right) R O E,
$$

where reinv is a reinvested portion of earnings;

declare_div are declared dividends;

$N /$ is net income.

The return on equity is broken down into distinct elements using the DuPont equation:

$$
R O E=\frac{N I}{E}=\frac{N I}{T R} \frac{T R}{A} \frac{A}{E}=\frac{N I}{E B T} \frac{E B T}{E B I T} \frac{E B I T}{T R} \frac{T R}{A} \frac{A}{E},
$$

where $N I / T R$ is the return on sales;

$T R / A$ is asset turnover;

$A$ / $E$ is financial leverage;

NI / EBT is tax burden;

$E B T / E B I T$ is interest burden;

\footnotetext{
${ }^{5}$ Lyubushin N.P., Babicheva N.E., Usachev D.G., Shustova M.N. [Genesis of the concept of sustainable development of economic systems of various hierarchical levels]. Regional'naya ekonomika: teoriya i praktika $=$ Regional Economics: Theory and Practice, 2015, no. 48, pp. 2-14. (In Russ.)
}

$E B I T / T R$ is operating income margin.

The return on sales and assets turnover denote the company's operating policies. The return on sales describes the products, company's position in the market and performance of production management.

The reinvestment rate and financial leverage reflect the financing activity. The reinvestment rate depends on the use of internal finance and dividend policy.

Financial leverage dictates fund raising policies and measures total net assets per unit of equity.

Hence, sustainable growth gains momentum when sales increase, with the return on sales, asset turnover, savings rate and financial leverage remaining unchanged. The balanced scorecard on growth management is created likewise it is done under the value concept.

There is a broad and narrow interpretation of corporate growth, i.e. the company's extension, establishment of new departments, increased revenue, comparison of revenue growth rates with the market growth, as a whole, corporate value growth.

Some researchers evaluate corporate growth through sales growth $[17,18]$, while the other rely upon trends in the number of employees.

Are such indicators, however, applicable depending on a type of economic activities and the company's development phase?

As some scholars define, growth is the ratio of the company's turnover trends to the average indicator registered in the type of economic activity the company is engaged in.

Corporate growth can be perceived through a growth in revenue, which can be decomposed into multiple factors. I should also mention the ratio of revenue growth to the average indicator assessed for competitors, market ratio (comparison with the market index, say, S\&P 500), GDP growth in case the company's activities are compared by segment and country. Thus, it is necessary to differentiate the absolute and relative growth of the company in comparison with the market. 


\section{Empirical Research, Probabilistic Modeling}

Drawing upon the panel sample of large public companies as provided in the Bloomberg data base from 2010 through 2015 and adjusted for a certain phase of the life cycle, I start a modeling process so as to substantiate and identify the way financial and economic results correlate with the corporate development phase. As I find out, current indicators have a positive effect, i.e. current ratio $(C R)$ and market capitalization of the company $(M C)$, and the number of employees (NE) on a growing company (Table 1).

Rapidly growing companies do have the highest market value of their equity:

$$
p=\frac{1}{\left(1+e^{-Z}\right)},
$$

where $p$ is the probability for being at the growth phase.

$$
Z=a_{i t}+b_{1} C R_{i t}+b_{2} M C_{i t}+b+3 N E_{i t}+\varepsilon_{i t},
$$

where $C R$ is the current liquidity ratio, i.e. the ratio of current assets to current liabilities;

$M C$ is the market capitalization of the company;

$N E$ is the number of employees.

Pursuing the other objective of the research, I evaluate the future development, i.e. the probability of the company's transition to a new phase of its life cycle.

As stated in fundamental researches into the life cycle concept development, the potential growth does depend on internal corporate distinctions relating to the majority owners' preferences and other characteristics of agency relations.

However, conventional researches omitted an external impact, under other equal circumstances, and hypothesized the macroeconomic stability. It may lead to ambiguous results.

Macroeconomic factors are also reviewed through another key sub-system that influences the corporate growth. The issue is contemplated for further researches.
For purposes of the same panel sample, I model the corporate growth probability, when the financial leverage factors influence growth opportunities.

If the independent variable rises, the company is more likely to quit the slow growth phase and assume the rapid growth phase (Fig. 4).

The third objective of the research is to determine key parameters aggravating the unsustainable growth of the company (Fig. 5).

I devise an economic and mathematical model tracing the dependence of unsustainable growth (downward trend) on financial factors, management quality factors.

To detect the unsustainable growth, I find the factors that decrease the operating income margin and revenue by over 15 percent in comparison with the average. If the indicators fall more than by 15 percent, I assign 1 to the criteria and 0 in the other cases. I build logit models to evaluate whether factors of revenue and operating income margin are likely to decrease:

$$
\begin{aligned}
& p=\frac{1}{\left(1+e^{-Z}\right)}, \\
& Z=a_{i t}+b_{1} M C_{i t}+b_{2} N E_{i t}+b_{3} C R_{i t}+ \\
& +b_{4} \text { finlev }_{i t}+b_{5} \frac{D}{E}+b_{6} \text { growth }+ \\
& +b_{7} \text { boost }+b_{8} \text { mature }+b_{9} \text { decline }+\varepsilon_{i t} \text {, }
\end{aligned}
$$

where finlev is financial leverage, the ratio of the company's debt to its assets;

$D / E$ is the ratio of the company's debt to equity;

growth is a dummy variable of slow growth. It becomes 1, if the company is at the slow growth phase, and 0 in the other cases;

boost is a dummy variable of rapid growth. It becomes 1, if the company undergoes a rapid growth, and 0 in the other cases;

mature is a dummy variable of maturity. It becomes 1 , if the company reaches its maturity, and 0 in the other cases;

decline is a dummy variable of decline. It becomes 1 , if the company's activities are declining, and 0 in the other cases. 
The modeling led to the following outcome:

- in case of a 1-percent error in the deviation of an incorrect hypothesis, the company's decline phase increases the probability of unsustainable growth and drop in the operating income margin (growth criteria). It results from a decrease in sales and increase in the cost;

- in case of a 10-percent error, an increase in the debt-to-total asset ratio fuels an unsustainable growth, probable downward deviation from the average value;

- in case of a 5-percent error, the slow growth phase decreases the probability of the operating income margin reduction;

- unsustainable growth becomes more probable by 4.6 percent if the debt-to-total asset ratio increases;

- unsustainable growth decreases by 12 percent if the company undergoes the slow growth phase.

Thus, the corporate growth is proved to be a complex and multifaceted process.

\section{Table 1}

Modeling the impact on the company's being at the growth stage

\begin{tabular}{ll}
\hline Factor & Interpretation of revealed relationships \\
\hline Current ratio - the current assets-to-current liabilities ratio $C R^{*}$ & Positive effect on the growth-phase position \\
\hline The number of employees $N E^{*}$ & Positive effect on the growth-phase position \\
\hline Market capitalization of the company $M C^{*}$ & Positive effect on the growth-phase position \\
\hline
\end{tabular}

* Significance of the independent factor at a 1-percent level.

${ }^{* *}$ Significance at a 5-percent level.

Source:Authoring
If a growth is traditionally considered as a pace, at which revenue and profitability factors grow, it gives ambiguous results, which overlook possible development scenarios, present static data and cause a significant reduction in profit and value in the future.

Most economic models focus on the dependence of financial and economic results on internal corporate qualities and figures.

Those models do not imply any adjustments for a life cycle phase. The life cycle concepts mostly provide a description of changes in organizational characteristics. They have been modified recently through financial and economic parameters.

Sustainable growth studies are carried out in dynamics, requiring a consistency of the analysis (Fig. 6).

Identifying and studying sub-systems, their relationship and trends help refine the findings and conclusions on a sustainable growth of the company in line with possible changes. 


\section{Figure 1}

Determinants and constraints at different stages of life cycle

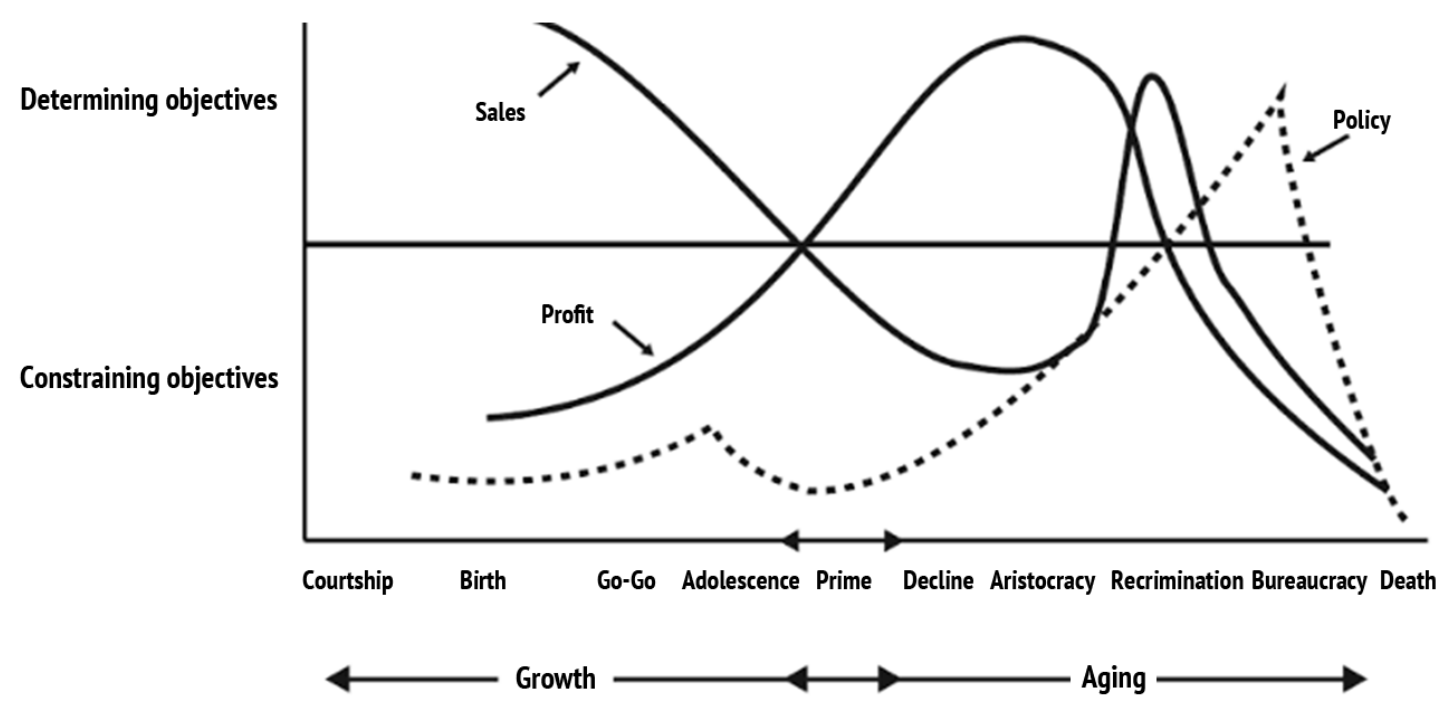

Source:[8]

\section{Figure 2}

Influence of concentration on agency conflicts

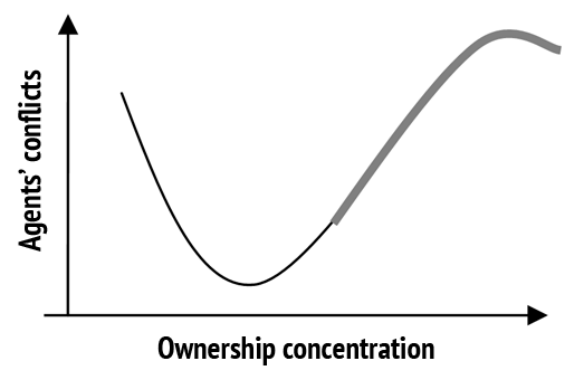

Source: Authoring 
Figure 3

Influence of concentration on financial leverage

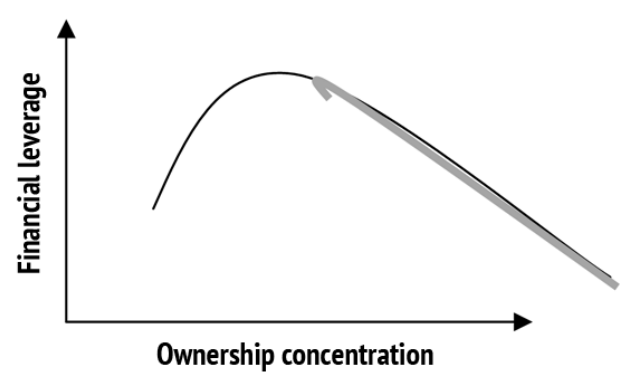

Source: Authoring

\section{Figure 4}

Simulating the probability of transition from slow growth to rapid growth stage

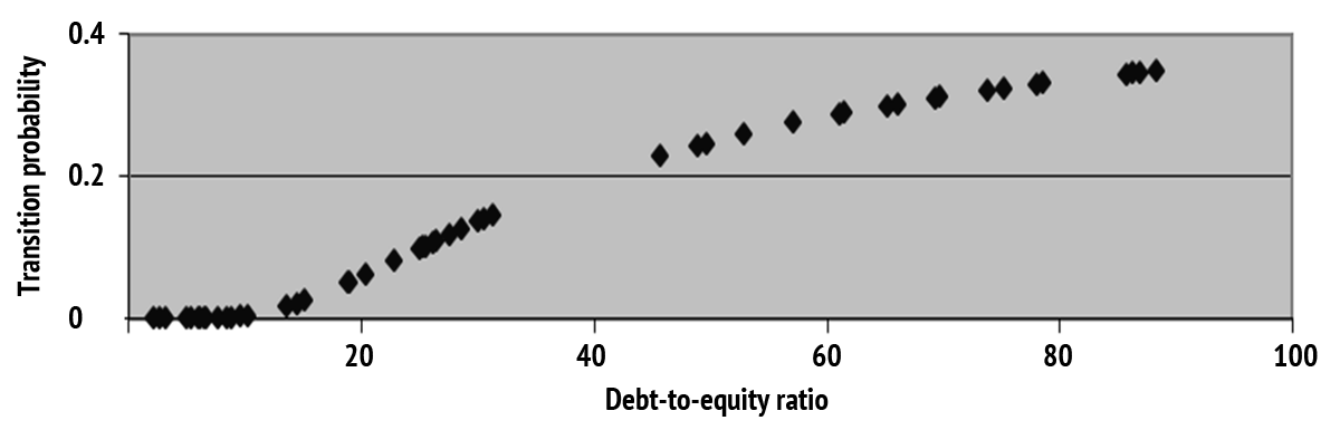

Source: Authoring

\section{Figure 5}

Simulating the probability of unsustainable growth

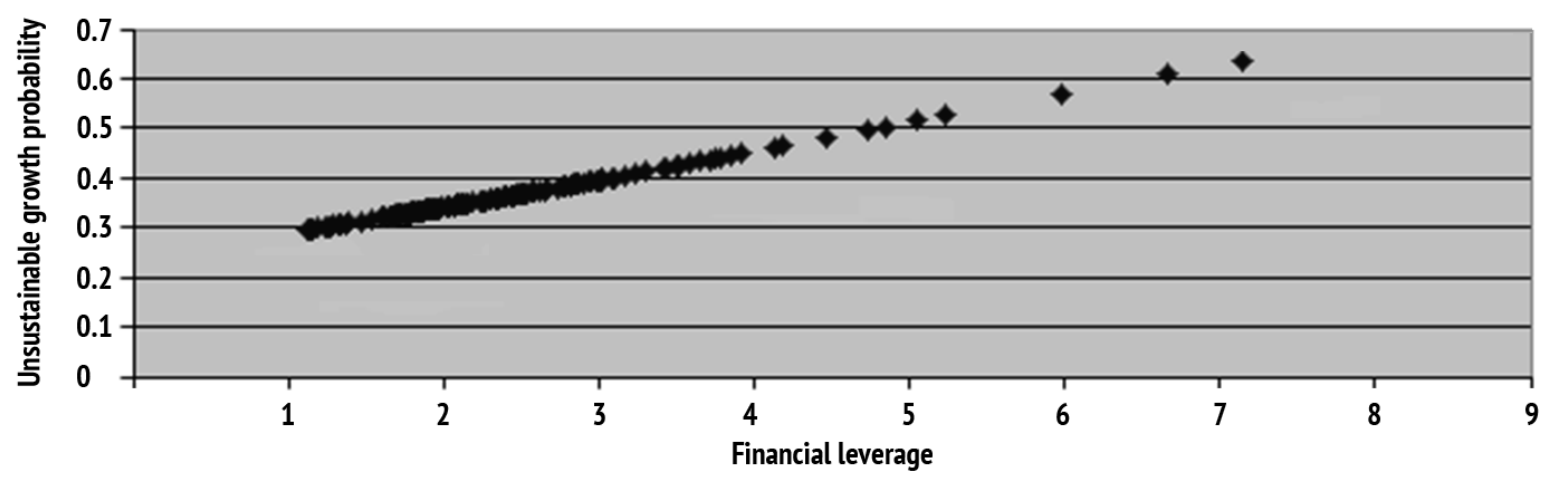

Source: Authoring 


\section{Figure 6}

Systemic description of impact factors on company's sustainable growth

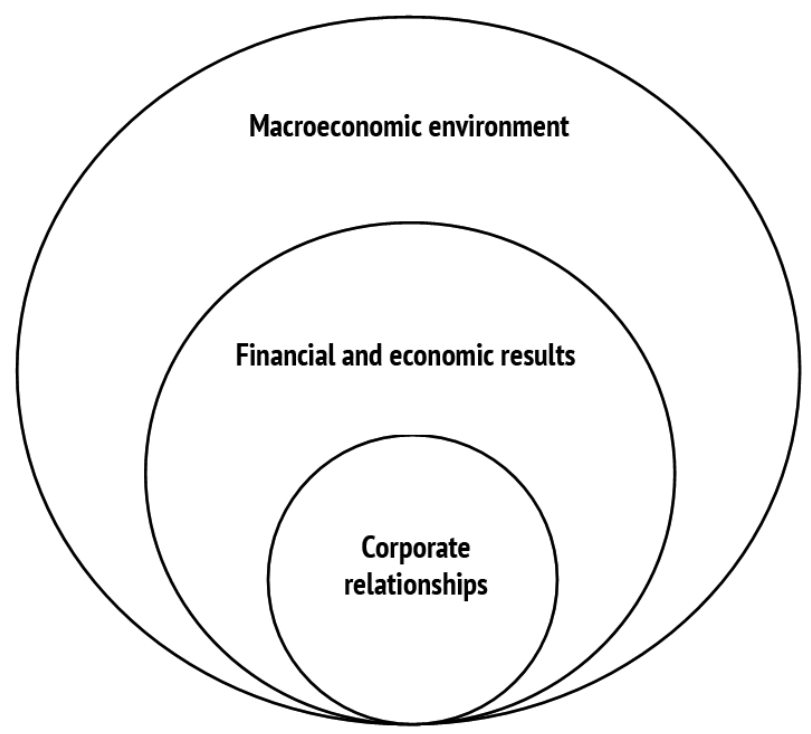

Source: Authoring

\section{Acknowledgments}

The article was supported by the Russian Foundation for Humanities, grant No. 15-32-01297a2.

\section{References}

1. Entov R.M., Radygin A.D. Struktura sobstvennosti i problemy korporativnogo kontrolya v rossiiskoi ekonomike [Ownership structure and corporate control problems in the Russian economy]. Moscow, Gaidar Institute Publ., 1999, 67 p.

2. Mal'ginov G.N., Radygin A.D. Smeshannaya sobstvennost'v korporativnom sektore: evolyutsiya, upravlenie, regulirovanie [Mixed ownership in the corporate sector: Evolution, management, regulation]. Moscow, Gaidar Institute Publ., 2007, 636 p.

3. Radygin A.D., Entov R.M. Korporativnoe upravlenie i zashchita prav sobstvennosti: empiricheskii analiz i aktual'nye napravleniya reform [Corporate governance and property rights protection: An empirical analysis of current trends and reforms]. Moscow, Gaidar Institute Publ., 2001, 294 p.

4. Rossiiskaya korporatsiya: vnutrennyaya organizatsiya, vneshnie vzaimodeistviya, perspektivy razvitiya [A Russian corporation: Internal organization, external cooperation and development prospects]. Moscow, Yustitsinform Publ., 2009, 542 p.

5. Greiner L.E. Evolution and Revolution as Organizations Grow. In: Readings in Strategic Management. David Asch, Cliff Bowman (eds). Macmillan Education, 1989, pp. 373-387. URL: https://doi.org/10.1007/978-1-349-20317-8

6. Adizes I. Corporate Lifecycles: How and Why Corporations Grow and Die and What to Do About It. Englewood Cliffs, N.J., Prentice Hall, 1988.

7. Adizes I. Organizational Passages: Diagnosing and Treating Life Cycle Problems in Organization. Organizational Dynamics, 1979, vol. 8, no. 1, pp. 3-25. 
8. Adizes I.K. Upravlenie zhiznennym tsiklom korporatsii [Managing Corporate Lifecycles: How Organizations Grow, Age, and Die]. Moscow, Eksmo Publ., 2016, 512 p.

9. Miller D., Friesen P.H. A Longitudinal Study of the Corporate Life Cycle. Management Science, 1984, vol. 30, iss. 10, pp. 1161-1183. URL: https://doi.org/10.1287/mnsc.30.10.1161

10. DeAngelo H., DeAngelo L., Stulz R.M. Dividend Policy and the Earned/Contributed Capital Mix: A Test of the Life-Cycle Theory. Journal of Financial Economics, 2006, vol. 81, iss. 2, pp. 227-254. URL: https://doi.org/10.1016/j.jfineco.2005.07.005

11. Lester D.L., Parnell J.A., Carraher A. Organizational Life Cycle: A Five Stage Empirical Scale. The International Journal of Organizational Analysis, 2003, vol. 11, iss. 4, pp. 339-354. URL: https://doi.org/10.1108/eb028979

12. Shirokova G.V. Zhiznennyi tsikl organizatsii: kontseptsii i rossiiskaya praktika [The life cycle of the organization: Concepts and Russian practice]. St. Petersburg, Saint Pertersburg State University Publ., 2007, 480 p.

13. Shirokova G.V. [Organization's life cycle theory: Analysis of major models]. Menedzhment $v$ Rossii i za rubezhom = Management in Russia and Abroad, 2007, no. 2, pp. 15-22. (In Russ.)

14. Shirokova G.V., Merkur'eva I.S., Serova O.Yu. [Specifics of life cycle formation of Russian companies (an empirical analysis)]. Rossiiskii zhurnal menedzhmenta = Russian Management Journal, 2006, vol. 4, no. 3, pp. 3-26. (In Russ.)

15. Stepanova A.N., Balkina E.A. [Corporate Financial Architecture at different lifecycle stages: Performance Effect in Russia]. Korporativnye finansy, 2013, vol. 7, no. 3. (In Russ.)

URL: https://cfjournal.hse.ru/article/view/1505

16. Rodionova V.M., Fedotova M.A. Finansovaya ustoichivost' predpriyatiya v usloviyakh inflyatsii [Financial sustainability of an enterprise under inflation]. Moscow, Perspektiva Publ., 1995, 98 p.

17. Weinzimmer L.G., Nystron P.C., Freeman S.J. Measuring Organizational Growth: Issues, Consequences and Guidelines. Journal of Management, 1998, vol. 24, iss. 2, pp. 235-262.

18. Wiklund J. The Sustainability of the Entrepreneurial Orientation-Performance Relationship. Entrepreneurship Theory and Practice, 1999, vol. 24, iss. 1, pp. 37-48.

\section{Conflict-of-interest notification}

I, the author of this article, bindingly and explicitly declare of the partial and total lack of actual or potential conflict of interest with any other third party whatsoever, which may arise as a result of the publication of this article. This statement relates to the study, data collection and interpretation, writing and preparation of the article, and the decision to submit the manuscript for publication. 